\title{
Islamisasi Teori Konsumsi Masyarakat Muslim Modern
}

\author{
Sabila Rosyida ${ }^{1}$ dan A'yun Nadhira ${ }^{2}$ \\ 1 Mahasiswi Pasca Sarjana Program Studi Hukum Ekonomi Syariah, Fakultas Syari'ah, Universitas \\ Darussalam Gontor \\ 2 Mahasiswi Pasca Sarjana Program Studi Hukum Ekonomi Syari'ah, Fakultas Syari'ah, Universitas \\ Darussalam Gontor \\ Email: sabilarosyida95@gmail.com, ayunnadhira@gontor.ac.id
}

\begin{abstract}
Since the spread of modernization to all corners of the world, human life, especially Muslims, has undergone many changes regarding perspectives and behavior towards various kinds of individual and community groups. One of the effects of modernization has led to large-scale economic changes, especially in people's consumption behavior due to the abundance of objects of service, and the availability of material goods on the market. The purpose of consumption in modern society is not only to fulfill the needs of life but also for pleasure and desire and mere satisfaction. So that their lives are based on the ideology of hedonism, the main purpose of which is only to obtain material pleasures and pleasures. Thus, Islamization of consumer behavior is needed to free Muslim society from secular doctrine and materialistic nature. And Islam offers the concept of maslaha and the nature of moderation based on Islamic economic ethics on this consumption theory. The method used is qualitative research methods with library research (library research). The data in this study were obtained using the documentary method, to look for data on consumption behavior of modern society, consumption theory, concepts and processes of Islamization, sourced from books, journals, the internet, and papers. Data analysis methods used are inductive, and comparative descriptive analysis.
\end{abstract}

Kata Kunci: Islamization, consumption theory, modernization 


\section{PENDAHULUAN}

Modernisasi merupakan masa dimana kehidupan manusia yang mengalami perubahan mengenai cara pandang terhadap berbagai macam persoalan yang menyangkut suatu individu ataupun kelompok masyarakat dengan melakukan suatu tindakan yang praktis untuk mengatasinya. Modernisasi ada karena masuknya budaya dan worldview Barat disebabkan karena adanya proses sekularisasi. Tentunya pengaruh tersebut menghasilkan dampak yang sangat luas kepada sistem kebudayaan yang ada pada masyarakat Muslim, dan mempengaruhi pola serta gaya hidup mereka yang berujung kepada perubahan perilaku masyarakat setempat. ${ }^{1}$

Dampak dari modernisasi ini menyebabkan perubahan ekonomi secara besar-besaran, terutama pada perilaku konsumsi masyarakat dikarenakan terbentuknya objek jasa yang melimpah ruah, dan barang-barang material yang tersedia di pasar. Sehingga tujuan konsumsi pada masyarakat modern bukan hanya untuk memenuhi kebutuhan hidup mereka, melainkan juga untuk kepentingan kesenangan dan keinginan semata. ${ }^{2}$

Selain itu, kebanyakan dari prilaku konsumsi masyarakat Muslim tidak lagi berdasarkan kepada dimensi spiritual, namun sudah beralih kepada konsep kapitalis yang mendasarkan segala sesuatunya kepada ukuran materialis. Seperti yang terlihat pada fenomena yang terjadi di masyarakat dimana mereka terperangkap pada pemakaian kartu kredit yang berlebihan akibat dorongan dari keinginan dan kesenangan semata, sehingga terjadi peningkatan hutang yang luar biasa dikarenakan adanya mekanisme bunga (interest rate) yang menjalar bersama sistem hutang tersebut. ${ }^{3}$

Hal tersebut dikarenakan adanya pengaruh dari Barat atau kapitalis dengan ideologi hedonisme yang mana tujuan utamanya hanya untuk mendapatkan kenikmatan dan kesenangan materi semata. Dan ketika mereka sudah berasaskan kepada perilaku hedonis maka sebisa mungkin mereka akan mempertahankan gengsinya untuk tetap mengikuti gaya hidup mewah sesuai dengan keinginan dan kepuasan mereka yang menyebabkan timbulnya hal-hal patologis dalam ekonomi, seperti hutang dan menghalalkan segala transaksi jual-beli walaupun tidak sesuai dengan etika dan moral. Hedonisme dalam pengertian ini akan mengancam dan merusak masa depan umat manusia dan lingkungannya. ${ }^{4}$

${ }^{1}$ Naquib Al-Attas, Islam and Secularism (Kuala Lumpur: (ABIM); reprint, Kuala Lumpur: (ISTAC), 1978), p.

2 Yohanes, S K. dan Peter, R P.“Segmentasi Gaya hidup pada Mahasiswa Program Studi Pemasaran Universitas Kristen Petra", Jurnal Jurusan manajemen Pemasaran, Fakultas Ekonomi Universitas Kristen Petra, 2006, p. 15

${ }_{3}^{3}$ Nurnasrina, "Ekonomi Islam Sarana Dalam Mewujudkan Ekonomi Masyarakat Madani”, Hukum Islam, (Nol. XIII, No. 1, November 2013), p. 222

4 Sri Sudarsih, Konsep Hedonisme Epikuros Dan Situasi Indonesia Masa Kini, (Semarang: UNDIP, 2007), p. 1 
Adapun teori prilaku konsumen yang dikembangkan oleh Barat merupakan sumber dualitas antara "rasionalisme ekonomi" dan "utilitarianism". Yang mana didalamnya teori ini mempertimbangkan tujuan dari para konsumer adalah "bomo-economicus" yaitu mendapatkan kepuasan dengan memandang bahwa uang adalah segalanya dan sangat dibutuhkan untuk mewujudkan kepuasan tersebut. ${ }^{5}$ Sedangkan dalam Islam segala teori aspek kehidupan yang ada di dunia harus berdasarkan pada konsep ketuhanan dimana Tuhan memegang peran yang sangat penting di atas segala sesuatu. Dalam hal ini, konsep Tauhid dan rujukannya (Al-Qur'an dan Sunnah) menjadi unsur yang sangat penting dalam Islamisasi ilmu ekonomi. Karena semua hal yang berkaitan dengan teori ilmu ekonomi, haruslah berasaskan kepada konsep Tauhid. Jika melenceng dari konsep tauhid, maka teori itu tidak dapat dilaksanakan.

Berdasarkan penjelasan singkat di atas, terlihat bahwa rasionalitas ekonomi ditujukan untuk memenuhi keinginan dengan capaian materialistis dan utilitarialism berfokus kepada kekuatan maximum individual yang bersifat subjektif. Dualitas yang memprakarsai timbulnya prilaku konsumsi ini memberikan dampak negatif terhadap masyarakat yaitu muculnya sifat materialisme dan egoisme dengan mementingkan kepentingan pribadi serta acuk tak acuh terhadap realitas sosial. Selain itu, yang menjadi permasalahan disini adalah prioritas konsumsi yang lebih condong pada kepuasan dimana kebutuhan dinilai sama dengan keinginan dan keinginan akan ditentukan oleh tingkat kepuasan yang ingin dicapai. Jika semua individu hanya fokus kepada kepuasan konsumsi maka hanya segelintir orang yang dapat memenuhi kepuasan maximumnya. Perilaku konsumsi yang demikian akan menimbulkan kesenjangan sosial. Dan tidak dapat menjawab problem ekonomi seperti kemiskinan karena menafikan norma sosial dalam prilaku konsumsi.

Oleh karena itu, diperlukan Islamisasi pada perilaku konsumsi untuk membebaskan masyarakat dari doktrin sekuler dan sifat materialistis. Islam menawarkan konsep maslahah terkait dengan prilaku konsumsi dan sifat moderity (ditengah-tengah) berdasarkan etika konsumsi Islam. Dalam tulisan ini akan dibahas teori konsumsi dalam konteks konvensional dan Islam, kemudia Islamisasi teori konsumsi dan analisis koherensi terhadap Islamisasi al-Attas dan al-Faruqi.

\section{HASIL DAN DISKUSI}

\section{Konsep Islamisasi Ilmu}

Islamisasi menurut Al-Attas adalah pembebasan akal fikiran manusia dari segala hal yang berbau magis atau sihir, mitologi, animisme, tradisi dan kultur nasional serta sekuler yang mana hal itu semua yang mengontrol segala fikiran manusia dan bahasa manusia. Maka, ia sangat menegaskan

\footnotetext{
${ }^{5}$ Sadono Sukirno, Mikro Ekonomi Teori Pengantar, Ed. 3, (Jakarta: PT Raja Grafindo Persada, 2013), p. 154.
} 
bahwasanya pemikiran, bahasa, prilaku umat Muslim tidak boleh dikontrol oleh tradisi sekuler ataupun hal-hal yang berbau Barat lainnya. ${ }^{6}$ Adapun menurut Al-Faruqi, Islamisasi ilmu pengetahuan adalah mengislamkan disiplin-disiplin ilmu atau tepatnya menghasilkan buku-buku pegangan (buku dars) di perguruan tinggi dengan menuangkan kembali disiplin-disiplin ilmu modern dalam wawasan Islam setelah mengkritisi kedua sistem ilmu pengetahuan Islam dan Barat. Dalam hal ini Al-Faruqi tidak langsung membuang nilai-nilai Barat yang ada di dalam ilmu pengetahuan tersebut, melainkan membuang jika tidak sesuai dengan nilai dan worldview Islam, menata, menganalisa dan menafsirkan ulang dan menyesuaikan ilmu Barat yang mana yang sesuai dan yang tidak sesuai dengan nilai dan worldview Islam. ${ }^{7}$

Apabila diperhatikan dengan seksama yang terjadi saat ini banyak sekali sistem pendidikan Barat modern yang membuat umat Muslim condong ke arah sekuler, yang menyebabkan mereka masih terbelenggu dan tidak bebas dari segala pengaruh negatif sihir, mitologi, animisme dan sekularisme. Al-Attas memikirkan konsep bagaimana caranya untuk membebaskan manusia dari unsur-unsur sekularisme yang muncul didalam ilmu pengetahuan Barat kontemporer tersebut. Karena proses Islamisasi tidak dapat dilaksanakan sebelum membebaskan pikiran dan jiwa dari segala hal yang berbau sekularisme tersebut. ${ }^{8}$ Menurut al-Faruqi semua disiplin ilmu pengetahuan seperti humaniora, ilmu-ilmu sosial dan ilmu alam harus dipertimbangkan dan dibangun kembali, agar semua cabang ilmu pengetahuan tersebut dibasiskan kembali kepada Islam. Semua disiplin ilmu itu harus disusun kembali agar dapat mewujudkan prinsip-prinsip Islam dalam metodologi, strategi, dan segala yang termasuk data, masalah, tujuan dan aspirasi dari segala cabang ilmu.

Segala cabang ilmu pengetahuan yang dikembangkan dalam paradigma sekularisme membawa dampak kegagalan pada manusia dan tidak sesuai bagi umat Islam. Al-Attas memperingatkan seluruh umat Islam bahwa mereka telah gagal dalam memahami fenomena yang terjadi, yaitu mereka menganggap bahwa semua ilmu pengetahuan adalah netral, bersifat universal dan berlaku dimanapun dan kapanpun, menurut al-Attas hal ini justru menciptakan banyak masalah dan akan berujung pada kerusakan worldview Islam dan norma-norma yang ada didalamnya. Hal itu disebabkan karena terjadinya asimilasi atau perbauran antara dua kebudayaan yang berbeda, yaitu antara kebudayaan Islam dan Barat atau Sekuler, sehingga ciri khas kebudayaan Islam yang asli hilang dan menyebabkan krisis agama, sosial dan ekonomi.

\footnotetext{
${ }^{6}$ Naquib Al-Attas, Islam and Secularism..., p. 119

${ }^{7}$ Isma’il Raji al Faruqi, Islamisasi Pengetahuan (terj), (Bandung: Pustaka, 1995), p. 35

${ }^{8}$ Naquib Al-Attas, Islam and Secularism .., p. 15
} 
Pengaruhnya tidak hanya merasuki aspek kehidupan Barat, namun juga telah menyebar pada pemikiran Muslim dimana-mana. ${ }^{9}$

Al-Attas memasukkan makna keadilan dan pengenalan dalam penggunaan ilmu pengetahuan. Sebab, dalam makna keadilan, ilmu pengetahuan harus diletakkan pada tempatnya. Dan kebenaran haruslah diletakkan pada tempatnya. Ilmu pengetahuan bukan dipergunakan untuk sesuatu hal yang berbau kejahatan, melainkan diletakkan pada tempatnya. Berarti seseorang yang berilmu harus mampu mengenali dan mengakui fenomena yang ada berdasarkan pada kebenaran dan kepastiannya. Dalam makna pengenalan, manusia harus mengenali dirinya sendiri, harus mampu memahami dirinya sendiri. Jika seorang manusia sudah gagal untuk mengenali dan memahami dirinya sendiri maka ia gagal dalam mengenal dan memahami Tuhannya. Maka jika ada seseorang yang salah paham terhadap Tuhannya, akhirnya ia akan salah dalam menempatkan Tuhannya dan salah pula dalam menempatkan dirinya dan ilmu pengetahuan yang ia miliki. ${ }^{10}$

Al-Attas merumuskan tujuan pendidikan dalam Islam yaitu, harus mewujudkan manusia yang baik, yaitu manusia yang universal (Al-Insan Al-Kamil). Maksud dari Insan Kamil adalah manusia yang mempunyai kriteria: pertama, manusia yang seimbang, yang mana memiliki keterpaduan dua dimensi kepribadian; dimensi isoterik vertikal yang mana ia selalu tunduk dan taat kepada Allah SWT dan dimensi eksoterik, dialektikal, horisontal, yang mana membawa misi keselamatan bagi lingkungan sosial alamnya. Kedua, manusia yang seimbang dalam kualitas pikir, zikir, dan amalnya. ${ }^{11}$ Dan tujuan ini tidak akan bisa diwujudkan tanpa adanya suatu upaya yang maksimal dalam merumuskan sistem pendidikan Islam yang terpadu.

Dalam konsep Al-Attas tentang Ta'dib (adab) dipadukan antara konsep ilmu dan amal. Dijelaskan didalamnya setelah manusia dikenalkan akan posisinya dalam tatanan kosmik melalui proses pendidikan. Dan kemudian manusia diharapkan dapat mengamalkan ilmunya dengan baik di masyarakat berdasarkan adab, etika, dan ajaran agama. Maka jika segala perilaku manusia ini sudah sesuai dengan konsep Ta'dib, maka sudah merupakan setengah jalan dari proses Islamisasi.

Adapun, prinsip ilmu pengetahuan menurut Al-Faruqi terdiri dari tiga prinsip: pertama, penolakan terhadap segala sesuatu yang tidak berkaitan dengan realitas; maksudnya meniadakan segala hal yang berbau kebohongan dan penipuan dalam Islam. Segala sesuatu dalam agama terbuka untuk diselidiki dan dikritik. Dalam prinsip ini, seorang muslim dapat didefinisikan sebagai orang yang tidak menyatakan apa-apa kecuali sesuatu yang benar, yang tidak mengemukakan apa-apa kecuali kebenaran, sekalipun harus dengan mempertaruhkan nyawanya

9 Wan Mohd. Nor Wan Daud, The Beacon on the Crest of a Hill-A Brief History and Philosophy of the International Institute of Islamic Thought and Civilization (ISTAC), (Kuala Lumpur: ISTAC Malaysia, 1991), p.31

${ }^{10}$ Naquib Al-Attas, Islam and Secularism .., p. 73

${ }^{11}$ Muhaimin, Konsepsi Pendidikan Islam, Sebuab Telaah Komponen Dasar Kurikulum, (Solo :Ramadhani), p. 72-73 
sendiri. Maka, segala sesuatu yang melenceng dari prinsip tersebut seperti mengatakan kebohongan, melakukan penipuan, kecurangan dan sejenisnya merupakan hal-hal yang dibenci oleh Islam. Kedua, penolakan kontradiksi-kontradiksi hakiki; Melindungi dari kontradiksi di satu pihak, dan dari paradoks di lain pihak. Prinsip ini merupakan esensi dari rasionalisme. Tanpa hal ini tidak akan bisa lepas dari skeptisisme; karena suatu kontradiksi yang hakiki mengandung arti bahwa kebenaran dari masing-masing unsur kontradiksi tidak akan pernah diketahui. Ketiga, keterbukaan bagi bukti baru dan/atau yang bertentangan. Prinsip ini melindungi kaum muslimin dari literalisme, fanatisme, dan konservatisme yang mengakibatkan kemandegan dan mendorong kaum muslimin bersifat rendah hati intelektual. ${ }^{12}$

Menurut Al-Attas proses Islamisasi ilmu dilakukan dengan dua cara, yaitu: pertama, mengisolir unsur-unsur dan konsep-konsep kunci yang terbentuk oleh budaya dan peradaban Barat, dari setiap bidang ilmu pengetahuan modern saat ini, khususnya dalam ilmu pengetahuan humaniora. Namun, ilmu-ilmu alam, fisika dan aplikasi harus diislamkan juga khususnya dalam penafsiran-penafsiran akan fakta-fakta dan dalam formulasi teori-teori. Kedua, memasukan elemen-elemen dan konsep-konsep kunci Islam kedalam setiap cabang ilmu pengetahuan masa kini yang relevan. Konsep-konsep dasar Islam itu diantaranya adalah konsep din, konsep manusia (insan), konsep ilmu (ilm dan ma'rifab), konsep keadilan ('ad), konsep amal yang benar (amal sebagai $a d a b)$ dan semua istilah dan konsep yang berhubungan dengan itu semua, dan konsep tentang universitas (kulliyah, jami'ah) yang berfungsi sebagai bentuk implementasi semua konsepkonsep itu dan menjadi model sistim pendidikan. ${ }^{13}$

Selain itu, proses Islamisasi ilmu menurut Al-Faruqi adalah dengan lima proses yaitu: pertama, mengartikulasikan paradigma keilmuan Islam dengan membangun epistemologi Islam yang berdasarkan kepada: Transformasi teologi ke dalam framework konseptual dan mengelaborasi paradigma keilmuan yang telah digunakan sepanjang sejarah pemikiran Islam dengan tetap merujuk kepada Islam, kedua, mengembangkan metodologi Al-Qur'an dengan menyusun tema-tema dalam Al-Qur'an sesuai dengan ilmu-ilmu sosial dan fisik. Ketiga, mengembangkan metodologi dengan memahami sunnah dan mengaitkannya dengan konteks kekinian. Keempat, menguji kembali khazanah intelektual Islam, karena menurutnya khazanah intelektual Islam perlu diseleksi kembali untuk dipilih yang mana yang diterima dan yang mana yang ditolak. Kelima, mengkaji khazanah intelektual Barat, untuk dapat mengkritik epistemologi

12 Isma'il Raji Al-Faruqi, Al-Tawhid: Its Implications for Thought and Life, (Herndon, Virginia, U.S.A: , International Institute of Islamic Thought, 1992), p.45-46

${ }^{13}$ Naquib Al-Attas, Prolegomena, (Kuala Lumpur: International Institute of Islamic Thought and Civilization (ISTAC), 1995), p.144 
Barat Muslim perlu untuk memahami Barat terlebih dahulu, tanpa kritik terhadap epistemologi Barat, maka Muslim tidak dapat melakukan Islamisasi ilmu pengetahuan secara sempurna. ${ }^{14}$

Al-Faruqi menekankan bahwa sistem islamisasi harus diresapi dengan semangat keislaman yang tinggi. Harus menciptakan visi dan semangat Islam, dan harus tetap setia kepada tujuan ideologis Islam. Diniatkan demi Allah ta'ala. Segala sistem yang ada tidak diperbolehkan meniru sistem Barat. Meskipun hanya untuk menoleransi kebutuhan ekonomi, kebutuhan pragmatis dari siswa untuk pengetahuan profesional, kemajuan pribadi, atau keuntungan materi. Sistem harus disertai dengan visi Islam. ${ }^{15}$

\section{Metodologi Ekonomi Islam}

Dalam proses Islamisasi ilmu ekonomi, metodologi ilmu ekonomi merupakan hal yang penting dan mendasar karena melalui metodologi inilah kebenaran hukum atau teori diharapkan dapat tercapai. Perumusan teori-teori ataupun sistem untuk mendukung ekonomi Islam seharusnya diformulasikan berdasarkan worldview Islam tentang kehidupan. ${ }^{16}$ Dan teori serta sistem yang didasarkan pada worldview Islam harus berangkat dari sebuah metodologi yang berbeda dengan metodologi ilmu ekonomi saat ini. Metodologi dalam ekonomi memuat seperangkat kriteria, aturan dan prosedur yang digunakan untuk menguji sifat, ruang lingkup dan kinerja ilmu ekonomi. ${ }^{17}$

Meskipun metodologi ekonomi Islam dikatakan belum tersusun secara baku, namun upaya pada hal ini telah banyak dilakukan. Oleh karena itu, Islamisasi ilmu memiliki tujuan untuk memberikan landasan metodologi pengembangan ilmu pengetahuan berdasarkan visi Islam. Caranya dengan mengintegrasikan nilai-nilai etika Islam, wahyu Islam atau maqashid syariah ke dalam konstruksi keilmuan ekonomi.

Adapun kaitannya dengan metodologi Islam, salah satu tokoh yang pernah menawarkan pemikirannya adalah Ismail Raji al-Faruqi dengan prinsip dasar metodologi Islam, "the unity of Allah, the unity of creation, the unity of truth and the unity of knowledge, the unity of life and the unity of bumanity." " Jika ditelaah apa yang telah ditawarkan oleh al-Faruqi, maka nampak bahwa metodologi ini jauh berbeda dibandingkan dengan scientific approach. Scientific approach berbasis pada sesuatu yang empiris, secara tidak langsung pendekatan ini menafikan eksistensi Tuhan. Hal ini

14 Ibrahim A Ragab, "On The Nature and Scope of the Islamization Process: Towards Conceptual Clarification", dalam Intelectual Discourse, Internation Islamic University Malaysia, (Vol. 3, No. 2, 1995), p. 113-122

15 Isma'il Raji Al-Faruqi, Islamization of Knowledge: General Principles and Work Plan, Herndon, (U.S.A: International Institute of Islamic Thought, 1982), p. 9

${ }^{16}$ Monzer Kahf, Ekonomi Islam..., p. 5

${ }^{17}$ Arief Hoetoro, Ekonomi Islam: Pengantar Analisis Kesejarahan dan Metodologi, (Malang: BPFE, 2007), p. 245.

${ }^{18}$ Isma'il Raji Al-Faruqi, Islamization of Knowledge..., p. 22-23 
dikarenakan pandekatan ini menilai bahwa sebuah kebenaran harus diperoleh dengan a posteriori. Safi mencatat bahwa metodologi Barat memiliki dua kelemahan yaitu, pertama, terjebak kepada bias-bias empirisme yang mencapai puncaknya dalam pendekatan positivisme logis. Kedua, pencabutan wahyu ilahi sebagai sumber pengetahuan ilmiah. ${ }^{19}$ Akibat dari bias-bias metodologi ini adalah bahwa kebenaran ilmiah hanya dapat dibuktikan secara empiris dan logis atau bahkan harus sesuai dengan fakta-fakta yang terjadi. Sementara itu, metodologi tradisional Islam juga mengandung kelemahan yaitu membatasi ijtihad kepada penjelasan legalistik formal, terlalu atomistik dan terpaku kepada pemikiran analogis. ${ }^{20}$

Menurut Zubair Hassan, terdapat dua pendekatan metodologi yang selama ini digunakan dalam membangun ilmu ekonomi Islam. Yaitu all-or-nothing aproach dan step by step aproach. ${ }^{21}$ Pendekatan pertama berpegang pada prinsip 'syariah total atau tidak sama sekali', pada pendekatan ini seluruh teori dan konsep ekonomi konvensional dinegasikan dan diruntuhkan, untuk kemudian dibangun ilmu ekonomi Islam dengan definisi dan konseptualisasinya sendiri. Namun, kelemahan pendekatan ini seringkali tidak aplikatif dan sulit direalisasikan. Adapun pendekatan kedua merupakan pendekatan gradual tahap demi tahap. Dalam pendekatan ini terjadi proses filterisasi ilmu ekonomi konvensional dengan mengeliminasi konponen-komponen yang bertantangan dengan ajaran Islam. Meskipun terbilang aplikatif, namun pendekatan ini menghadirkan kritik bahwa ekonomi Islam hanya mengekor ekonomi konvensional semata sehingga orisinalitas keilmuannya sering dipertanyakan. ${ }^{22}$

Apabila diperhatikan dari segi prakteknya maka pendekatan kedua terbilang lebih dominan dibandingkan dengan pendekatan yang pertama. Namun yang menjadi permasalahan dan sering mendapat kritik adalah ketidakmampuan para ekonomi Islam untuk berfikir out of the box. Maksudnya, struktur ekonomi Islam seringkali didesain mengikuti struktur ekonomi konvensional dengan kerangka berfikir yang tidak terlalu berbeda. Sehingga kadang sulit membedakan antara keduanya. Sehingga berakibat muncul banyak pendapat yang menyatakan bahwa ekonomi Islam adalah ekonomi konvensional minus riba plus zakat dan bagi hasil. ${ }^{23}$

Dengan demikian, merujuk pada fakta dominasi pendekatan yang kedua, maka pilihan yang paling rasional dan aplicable untuk saat ini adalah dengan melakukan Islamisasi ilmu ekonomi

19 Louay M. Safi, The Foundation of Knowledge: A comparative Study in Islamic and Western Method of Inquiry, (Malaysia: IIUM Press, 1996), p. 19-20

${ }^{20}$ Arief Hatoero, Ekonomi Islam: Pengantar Analisis..., p, 250

21 Zubair Hassan, "Islamization of Knowledge: Issue And Agenda", dalam IIUM Journal of Economics and Management, (Vol.6, No. 2 1998), p. 32

${ }^{22}$ Irfan Syauqi Beik, "Islamisasi Ilmu Ekonomi”, dalam jurnal Islamiconomic.., p.185-186

${ }^{23}$ Ibid, p. 186 
melalui pendekatan yang bersifat integratif. Pendekatan ini adalah pendekatan dengan menjadikan ilmu ekonomi konvensional sebagai benchmark, dan kemudian dilakukan modifikasi dan insersi nilai-nilai Islam sehingga melahirkan ilmu ekonomi Islam yang memiliki perbedaan dengan ilmu ekonomi konvensional, baik dari sisi filosofis maupun dari sisi praktis. ${ }^{24}$

Terdapat dua jenis ilmu pengetahuan yang harus di kuasai oleh cendekiawan Muslim modern adalah, pertama, subtantive knowledge, yaitu menguasai ilmu pengetahuan modern, menguasai warisan intelektual Islam, antologi, analisis, konseptualisasi dan teorisasi ilmu ekonomi Islam. Kedua, Technical knowledge, berupa taksiran kritis terhadap ilmu pengetahuan modern, taksiran kritis terhadap warisan Intelektual Islam dan analisis kreatif serta perpaduannya. ${ }^{25}$

\section{Teori Konsumsi Konvensional}

Teori prilaku konsumen yang dikembangkan di Barat setelah timbulnya kapitalisme merupakan sumber dari dualitas, yakni "rasionalisme ekonomi” dan "utilitarianism."26 Dari sumber rasionalisme ekonomi dan utilitarianism inilah kemudian timbul prilaku konsumen. Rasionalisme ekonomi mengandung pengertian bahwa setiap konsumen akan mengkonsumsi barang sesuai dengan sifatnya sebagai homo economicus. Secara lebih spesifik konsumen akan bertindak untuk memenuhi kepentingannya sendiri, dan perhitungan dari setiap prilaku ekonomi untuk mencapai sukses senantiasa di ukur berdasarkan capaian yang bersifat materialistik. ${ }^{27}$ Teori ini mempertimbangkan maksimasi pemanfaatan sebagai tujuan konsumer yang dipostulasikan. Pemanfaatan yang dimaksimasikan adalah pemanfaatan "bomo-economicus" yang tujuan tunggalnya adalah mendapatkan kepuasan ${ }^{28}$ ekonomi pada tingkatan tertinggi dan dorongan satu-satunya adalah "kesadaran akan uang." 29

Teori ini terlahir dari teori utilitarianism yang seringkali disebut utilitarianism hedonis, yang berarti suatu pandangan yang mengukur benar atau salah berdasarkan kriteria kesenangan atau kesusahan, sesuatu dianggap baik dan benar jika memberikan kesenangan dan sebaliknya. Dengan dua nilai dasar yaitu rasionalisme ekonomi dan utilitarianism prilaku konsumsi seseorang akan bersifat individualis, diwujudkan dalam bentuk segala barang dan jasa yang dapat memberikan

\footnotetext{
${ }^{24}$ Irfan Syauqi Beik, "Islamisasi Ilmu Ekonomi”, dalam jurnal Islamiconomic.., p.186

${ }^{25}$ Muhammad Aslam Haneef, A Critical Survey Of Islamization Of Knowledge, (Malaysia: IIUM, 2005), p. 32

26 Max Weber, The protestant Ethic and the Spirit of Capitalism, (New York: Charles Scribners' Sons, 1958), p. 76

27 Hendri Anto, Pengantar Ekonomika Islami, (Yogyakarta: EKONESIA, 2003), p. 120

28 Didalam teori ekonomi, kepuasan atau kenikmatan yang diperoleh seseorang dari mengkonsumsikan barang-barang dinamakan nilai guna atau utiliti. Kalau kepuasan itu semakin tinggi maka makin tinggilah nilai gunanya atau utilitinya; Sadono Sukirno, Mikro Ekonomi Teori Pengantar, Ed. 3, (Jakarta: PT Raja Grafindo Persada, 2013), p. 154.

${ }^{29}$ Monzer Kahf, Ekonomi Islam..., p. 17
} 
kesenangan dan kenikmatan. Individu yang rasional akan melakukan pilihan terhadap barangbarang dan jasa yang dikonsumsi yang dapat memberikan manfaat, kegunaan, dan kekuasaan yang paling tinggi. Konsumen pun akhirnya bertindak rasional yang berarti konsumen selalu berusaha mencapai kepuasan yang maksimum untuk memenuhi kebutuhan-kebutuhannya. ${ }^{30}$

Dalam ekonomi konvensional konsep barang atau jasa adalah segala sesuatu yang mempunyai nilai guna yang dapat memberikan tingkat kepuasan kepada seseorang. Sementara konsep utilitas yang dimaksud adalah jika sesuatu tersebut dapat memberikan tingkat kepuasan maka dinamakan barang konsumsi. Pandangan utility ini sangat bersifat subyektif bagi masingmasing individu, dalam artian sesuatu yang dianggap memberikan nilai guna berupa pemenuhan rasa puas atas konsumsinya belum tentu akan memberi rasa puas pada individu yang lain. ${ }^{31}$ Dalam kerangka konvensional, kebutuhan selalu senilai dengan keinginan, dimana keinginan ditentukan oleh konsep kepuasan. Teori ekonomi konvensional menjabarkan kepuasan (utilitas) seperti memiliki barang/ jasa untuk memuaskan keinginan manusia. ${ }^{32}$ Pada dasarnya satu jenis benda ekonomi merupakan substitusi sempurna bagi benda ekonomi lainnya sepanjang memberikan utilitas yang sama (indeverence curve). Akibatnya, anggaran akan dialokasikan untuk mengkonsumsi apa saja sepanjang utilitasnya maksimum. Tidak ada benda ekonomi yang berharga daripada benda ekonomi lainnya, yang membedakan adalah tingkat kepuasan diperoleh akibat mengkonsumsi benda tersebut. Karenanya, benda yang memberikan utilitas lebih tinggi akan menjadi lebih berharga dibandingkan yang memberikan utilitas yang lebih rendah. ${ }^{33}$

Dengan demikian maka tujuan terakhir dari konsumsi tersebut adalah bagaimana seorang manusia mencapai tujuan maximum satisfaction (kepuasan maksimum) atau maximum utility. Yang mana konsumen akan membelanjakan sejumlah pendapatan mereka demi mencapai kepuasan maksimum. Dan dalam hal ini, keinginan manusia selalu didorong untuk dipenuhi, keinginan yang senantiasa ingin dipenuhi ini terkadang tidak didasarkan kepada kebutuhan, sehingga pengeluaran konsumsi tidak serta merta dapat dikontrol dengan baik. Akibatnya masyarakat hanya akan mementingkan kepuasan individual dan acuh tak acuh terhadap realitas sosial.

\section{Teori Konsumsi Islam}

Islam menawarkan konsep maslahah terkait dengan prilaku konsumsi, dan sifat moderity (ditengah-tengah) berdasarkan etika konsumsi Islam. Jika ditelaah lebih jauh, konsep Wants (keinginan) dan needs (kebutuhan) berasal dari tempat yang sama yaitu naluri hasrat manusia.

\footnotetext{
${ }^{30}$ Endang Setyowati et. al, Ekonomi Mikro Pengantar, (Yogyakarta: FTIE YKPN, 2003), p. 89

31 Ely masykuroh, Pengantar Teori Ekonomi "Pendekatan Pada Teori Ekonomi ISLAM, (Yogyakarta: STAIN

${ }^{32}$ Muhammad, Ekonomi Mikro Dalam Perspektif Islam, (Yogyakarta: BPFE, 2005), p. 152

${ }^{33}$ M.B Hendrie Anto, Pengantar Ekonomika Islami, p. 128-129
} Ponorogo Press, 2008), p. 146-147 
Namun, dalam kerangka Islami, seluruh hasrat manusia tidak bisa dijadikan sebagai needs. Hanya hasrat yang memiliki maslahah atau manfaat di dunia dan akhirat yang bisa dijadikan sebagai needs. Maka, seluruh aktivitas ekonomi yang mengandung kemaslahatan bagi umat manusia disebut sebagai kebutuhan (needs). Dengan demikian konsep wants adalah konsep yang bebas nilai, sedangkan konsep needs adalah konsep yang tidak bebas nilai. Dalam hal ini, Islam tidak memberikan dorongan kepada manusia untuk mengikuti keinginannya, tetapi sebaliknya mendorong manusia untuk memenuhi kebutuhannya seperti yang didefinisikan dalam syariah. ${ }^{34}$

Dalam perspektif Islam kebutuhan ditentukan oleh maslahah. Pembahasan konsep kebutuhan dalam Islam tidak dapat dipisahkan dari kajian prilaku konsumen dari kerangka maqashid syariah. ${ }^{35}$ Oleh karena itu, semua barang dan jasa yang memiliki maslahah akan dikatakan menjadi kebutuhan manusia. ${ }^{36}$ Menurut Syatibi, maslahah adalah kepemilikan atau kekuatan barang/jasa yang mengandung elemen-elemen dasar dan tujuan kehidupan ummat manusia di dunia ini. Syatibi membedakan maslahah menjadi tiga yaitu: kebutuhan (daruriyah), pelengkap (bajizah), dan perbaikan (tahsiniyah). ${ }^{37}$ Khallaf menjelaskan, daruriyah adalah sesuatu yang wajib adanya yang menjadi pokok hidup untuk menegakkan kemaslahatan manusia. Hajizah ialah suatu yang diperlukan oleh manusia dengan maksud untuk membuat ringan, lapang dan nyaman dalam menanggulangi kesulitan-kesulitan hidup. Tabsiniyah berpangkal dari tradisi yang baik dan segala tujuan peri kehidupan manusia menurut jalan yang paling baik. Menurutnya yang terpenting dari tiga tujuan pokok itu adalah daruriyah dan wajib dipelihara. Hajizah boleh ditinggalkan apabila memeliharanya merusak hukum darury, dan tahsiny boleh ditinggalkan apabila dalam menjaganya merusak hukum darury dan tahsiny. ${ }^{38}$ Syatibi menambahkan bahwa kemaslahatan hanya dapat dicapai dengan memelihara lima unsur pokok kehidupan, yaitu agama, jiwa, akal, keturunan, dan harta. ${ }^{39}$

Maka dengan demikian konsep kebutuhan tidak serta merta ditentukan oleh keinginan dan untuk kepuasan materil semata, melainkan juga ditentukan oleh konsep maslahah. Dimana tidak memberikan dorongan kepada manusia untuk mengikuti keinginannya, tetapi sebaliknya mendorong manusia untuk memenuhi kebutuhannya terlebih dahulu. Dalam Islam konsep kebutuhan yang membentuk pola konsumsi seorang Muslim, karena pola konsumsi yang hanya

34 Euis Amalia, Sejarah Pemikiran Ekonomi Islam, (Depok: Gramata Publishing, 2010), p. 258

35 Umer Chapra, Masa Depan Ilmu Ekonomi: Perspektif Islam, penerj. Ikhwan Abidin, (Jakarta: Gema Insani Press, 2002), p. 106

\footnotetext{
${ }^{36}$ Muhammad, Ekonomi Mikro..., p. 152

${ }^{37}$ Imam as-Syatibi, al-Muwafaqat fi Ushul al-Syari'ah, jilid. 2, ( Dar Ibn Affan, 1997), p. 7

38 Abdul Wahab Khallaf, Ilm Ushul Figh, (Kairo: Dar al-Qolam), p. 205-206

39 Imam as-Syatibi, al-Muwafaqat...., p. 8
} 
berdasarkan kepada kebutuhan semata akan menghindarkan dari pengaruh-pengaruh pola konsumsi yang tidak perlu. ${ }^{40}$

Manusia diberikan kebebasan untuk melakukan konsumsi barang dan jasa yang ada, atau memiliki perilaku konsumsi barang dan jasa secara bebas, namun didalam kebebasannya itu harus berpijak pada etika konsumsi yang telah diatur dalam ajaran Islam. Oleh karena itu etika konsumsi Islam selalu merujuk pada dasar "halalan thayyiban" dan sederhana. Kehalalan suatu barang konsumsi merupakan antisipasi dari adanya keburukan yang ditimbulkan oleh barang tersebut. Sebagai contoh pengharaman khamr dalam arti luas, adalah upaya antisipasi yang ditimbulkan baik bagi konsumen (secara jasmani maupun rohani) maupun terhadap orang lain. ${ }^{41}$ Meskipun barang-barang yang dikonsumsi adalah barang yang halal dan bersih dalam pandangan Allah, akan tetapi konsumen Muslim tidak akan melakukan permintaan terhadap barang yang ada dengan sama banyak atau menganggap semua barang sama penting sehingga pendapatannya habis. Tetapi perlu diingat bahwa manusia memiliki kebutuhan jangka pendek (dunia) dan juga kebutuhan jangka panjang (akhirat). ${ }^{42}$

Banyak norma-norma penting yang berkaitan dengan larangan bagi konsumen, diantaranya adalah ishraf dan tabdzir, juga norma yang berkaitan dengan anjuran untuk melakukan infak. Dalam kerangka Islam pengeluaran dibagi menjadi dua tipe. Pengeluaran tipe pertama adalah pengeluaran yang dilakukan seorang Muslim untuk memenuhi kebutuhan duniawinya dan keluarga dan pengeluaran tipe kedua adalah pengeluaran yang dikeluarkan semata-mata bermotif mencari akhirat. ${ }^{43}$ Prioritas konsumsi seseorang harus memiliki nilai dunia dan akhirat. ${ }^{44}$

Disisi lain, tujuan syariah memberikan dimensi berbeda terhadap problem ekonomi atas individu. Dalam syariah, keinginan ditempatkan setelah melihat maslahah. Aktivitas ekonomi baik produksi, konsumsi dan pertukaran itu mengandung maslahah sebagaimana dibatasi dalam syariah yang dicapai sebagai tugas keagamaan, yang diharapkan memberikan manfaat bukan saja didunia tetapi juga akhirat. ${ }^{45}$

Dalam hal ini, Islam tidak hanya mengubah nilai dan kebiasaan masyarakat tapi juga menyajikan kerangka legislatif yang perlu untuk mendukung dan memperkuat tujuan-tujuan ini

\footnotetext{
${ }^{40}$ Heri Sudarsono, Konsep ekonomi Islam: suatu pengantar, (Ekonisia: Yogyakarta, 2002), p. 152

${ }^{41}$ Muhammad, Ekonomi Mikro..., p. 172

42 Ibid, p. 175

${ }^{43}$ Muhammad, Ekonomi Mikro..., p. 167-168

44 Ibid, p. 173

${ }^{45}$ Monzer Kahf, Ekonomi Islam..., p. 156-157
} 
dan menghindari penyalahgunaannya. ${ }^{46}$ Oleh karena itu, diperlukan Islamisasi pada prilaku konsumsi untuk membebaskan masyarakat dari doktrin sekuler dan sifat materialistik

\section{Islamisasi Teori Konsumsi}

\section{Konsep Kebutuhan dan Keinginan}

Dalam Islamisasi konsep kebutuhan dan keinginan yang perlu diIslamisasi adalah cara pandang tentang kebutuhan dan keinginan. Dalam ekonomi konvensional kebutuhan dipandang memiliki nilai yang sama dengan keinginan. Dimana keinginan menjadi tujuan dari rasionalitas ekonomi untuk memenuhi kepuasan maksimum yang bersifat subjektif. Cara pandang ini akan melahirkan sifat materialistik, hedonis, kapitalis dan individualis. Yang menjadi permasalahan selain dampak dari hal tersebut adalah adanya persamaan pandangan antara kebutuhan dan keinginan. Tidak dibedakannya dua hal ini dapat berdampak pada konsumsi barang dan jasa yang berlebihan. Jika ditelaah lebih jauh, konsep kebutuhan (needs) dan keinginan (wants) berasal dari tempat yang sama yaitu naluri hasrat manusia. Namun, dalam kerangka Islami, seluruh hasrat manusia tidak bisa dijadikan sebagai needs. Hanya hasrat yang memiliki maslahah atau manfaat di dunia dan akhirat yang bisa dijadikan sebagai needs.

Untuk Islamisasi, pertama, perlu dipisahkan cara pandang yang mengatakan bahwa keinginan dan kebutuhan adalah sama. Kedua, meletakkan keinginan setelah maslahah. Konsep kebutuhan tidak serta merta ditentukan oleh keinginan dan untuk kepuasan materil semata, melainkan juga ditentukan oleh konsep maslahab ${ }^{47}$. Sebab, seluruh aktivitas ekonomi yang mengandung kemaslahatan bagi umat manusia disebut sebagai kebutuhan (needs). Dengan demikian konsep kebutuhan adalah konsep yang bebas nilai, sedangkan konsep keinginan adalah konsep yang tidak bebas nilai. Dalam hal ini, Islam tidak memberikan dorongan kepada manusia untuk mengikuti keinginannya, tetapi sebaliknya mendorong manusia untuk memenuhi kebutuhannya seperti yang didefinisikan dalam syariah. ${ }^{48}$ Oleh karena itu, semua barang dan jasa yang memiliki maslahah akan dikatakan menjadi kebutuhan manusia. ${ }^{49}$

\section{Konsep Barang dan Jasa}

Dalam ekonomi konvensional konsep barang atau jasa dalam konsumsi adalah segala sesuatu yang mempunyai utililty yang dapat memberikan tingkat kepuasan kepada seseorang.

46 Ibid, p. 28

47 Menurut Syatibi, maslahah adalah pemilikan atau kekuatan barang/jasa yang mengandung elemen-elemen dasar dan tujuan kehidupan ummat manusia di dunia ini. Maslahah dibedakan menjadi tiga yaitu: kebutuhan (daruriyab), pelengkap (hajiyah), dan perbaikan (tabsiniyab); Imam as-Syatibi, al-Munafaqat fi Ushul al-Syari'ah, jilid. 2, (Dar Ibn Affan, 1997), p. 7

${ }^{48}$ Euis Amalia, Sejarah Pemikiran Ekonomi Islam, (Depok: Gramata Publishing, 2010), p. 258

${ }^{49}$ Muhammad, Ekonomi Mikro..., p. 152 
Sementara konsep utilitas yang dimaksud adalah jika sesuatu tersebut dapat memberika tingkat kepuasan maka dinamakan barang konsumsi. Pandangan utility ini sangat bersifat subyektif bagi masing-masing individu, dalam artian sesuatu yang dianggap memberikan nilai guna berupa pemenuhan rasa puas atas konsumsinya belum tentu akan memberi rasa puas pada individu yang lain. ${ }^{50}$

Cara Islamisasi konsep barang dan jasa adalah pertama, mengganti konsep utility dengan maslahah. Kedua, dengan membatasi konsep barang dan jasa yang akan dikonsumsi melalui konsep ‘halalan tayyiban'. Konsep Barang konsumsi dalam konvensional jelas tidak dibatasi, sebagai mana dalam pernyataan 'segala sesuatu' diatas. 'Segala sesuatu' ini bisa menjadi apapun asal dapat memenuhi kepuasan seseorang entah itu baik atau buruk. Namun, dalam Islam konsep barang dan jasa dibatasi dalam istilah halalan tayyiban. Kehalalan suatu barang konsumsi merupakan antisipasi dari adanya keburukan yang ditimbulkan oleh barang tersebut. Sebagai contoh pengharaman khamr dalam arti luas, adalah upaya antisipasi yang ditimbulkan baik bagi konsumen (secara jasmani maupun rohani) maupun terhadap orang lain. $^{51}$

Prilaku memanfaatkan atau mengkonsumsi sesuatu yang baik dalam Islam dianggap sebagai kebaikan, karena kenikmatan yang dicipta Allah untuk manusia adalah ketaatan kepada-Nya. karena itu mu'min berusaha mencari kenikmatan dengan menaati perintah Allah dan memuaskan dirinya sendiri dengan barang-barang dan anugrah-anugrah yang diciptakan Allah untuk manusia. Konsumsi dan pemuasan kebutuhan tidak dikutuk dalam Islam selama keduanya tidak melibatkan hal-hal yang tidak baik atau merusak..$^{52}$ Namun demikian Islam tetap menganjurkan untuk tidak berlebih-lebihan.

\section{Konsep Kepuasan Konsumsi}

Dalam kerangka konvensional, keinginan ditentukan oleh konsep kepuasan. Teori ekonomi konvensional menjabarkan utilitas seperti memiliki barang/ jasa untuk memuaskan keinginan manusia. ${ }^{53}$ Dengan demikian maka tujuan terakhir dari konsumsi tersebut adalah mencapai kepuasan maksimum. ${ }^{54}$ Prilaku konsumsi saat ini tidak hanya untuk memenuhi

${ }^{50}$ Ely masykuroh, Pengantar Teori Ekonomi "Pendekatan Pada Teori Ekonomi ISLAM, (Yogyakarta: STAIN Ponorogo Press, 2008), p. 146-147

${ }^{51}$ Ibid, p. 172

${ }^{52}$ Monzer khaf, Eko nomi Islam..., p. 27-28

53 Muhammad, Ekonomi Mikro Dalam Perspektif Islam, (Yogyakarta: BPFE, 2005), p. 152

${ }^{54}$ Endang Setyowati et. al, Ekonomi Mikro Pengantar, (Yogyakarta: FTIE YKPN, 2003), p. 89 
kebutuhan, namun juga untuk kepentingan kesenangan dan prestise (harga diri). ${ }^{55}$ Dampak negatif yang timbul terhadap masyarakat, adalah munculnya sifat meterialis dan egoisme dengan mementingkan kepentingan pribadi serta acuh-tak acuh terhadap realitas sosial.

Selain itu, yang menjadi permasalahan disini adalah prioritas konsumsi yang lebih condong pada kepuasan materil. Dimana dalam asumsi konvensional kepuasan dinilai tidak terbatas, sedangkan sumberdaya terbatas. Terlebih lagi, ideologi kapitalisme ini secara praktis mengarah pada individu untuk mengejar tujuan yang tidak jelas. Dikatakan tidak jelas karena keinginan itu sendiri merupakan sesuatu yang samar-samar (tidak jelas), dan jika problem ekonomi itu dibatasi dengan istilah ini maka merupakan hal yang masih samar-samar.

Cara Islamisasi konsep kepuasan konsumen adalah pertama, dengan tidak menjadikan kepuasan sebagai prioritas utama dalam konsumsi. Kedua, menggunakan konsep maslahah sebagai landasan dasar dalam konsumsi. Selain itu terdapat asumsi yang perlu diluruskan yaitu asumsi konvensional tentang "kepuasan konsumen yang tidak terbatas, tapi sumber daya alam terbatas", bahwa pada hakikatnya sumber daya alam tidaklah terbatas, melainkan akan selalu ada karena Allah akan menjamin semua rezeki atau kebutuhan hidup tiap makhluk-Nya. ${ }^{56}$

Sebagaimana Islamisasi konsep keinginan dan kebutuhan melalui konsep maslahah, kepuasan konsumen juga menggunakan konsep maslahah, dengan meletakkan kepuasan setelah maslahah yakni dengan melakukan skala prioritas berdasarkan kebutuhan daruriyah, haijiyah dan tabsiniyah. Kepuasan konsumen cenderung pada sifat berlebih-lebihan, konsumsi yang berlebihan-lebihan, merupakan ciri khas masyarakat yang tidak mengenal Tuhan, dikutuk dalam Islam dan disebut dengan istilah israf (pemborosan) atau tabdzir (menghamburhamburkan harta tanpa guna). ${ }^{57}$ Islam menyarankan agar manusia dapat bertindak di tengahtengah (moderity) dan sederhana (simplicity). Kesederhanaan dalam konsumsi memiliki arti jalan tengah diantara dua cara hidup yang ekstrim antara paham materialstis dan zuhud. Banyak norma-norma penting yang berkaitan dengan larangan bagi konsumen, diantaranya adalah ishraf dan tabdzir, juga norma yang berkaitan dengan anjuran untuk melakukan infak. ${ }^{58}$ Selain itu, prioritas konsumsi seseorang harus memiliki nilai dunia dan akhirat. ${ }^{59}$

55 Yohanes, S K. dan Peter, R P.. "Segmentasi Gaya hidup pada Mahasiswa Program Studi Pemasaran Universitas Kristen Petra", Jurnal Jurusan manajemen Pemasaran, Fakultas Ekonomi Universitas Kristen Petra, 2016, p. 15

\footnotetext{
${ }^{56}$ Irfan Syauqi Beik, “Islamisasi Ilmu Ekonomi”, dalam jurnal Islamiconomic,...........hlm. 188

57 Ibid, p. 28

58 Muhammad, Ekonomi Mikro..., p. 167-168

${ }^{59}$ Ibid, p. 173
} 


\section{Analisis Kesesuaian Islamisasi Konsumsi terhadap Teori Islamisasi al-Attas}

Pada bagian ini, penulis akan menganalisis tentang kesesuian pembahasan Islamisasi konsumsi terhadap teori Islamisasi al-Attas, dengan merujuk beberapa contoh yang telah dibahas pada subbab sebelumnya.

Islamisasi teori konsumsi dari ketiga konsep yang telah dibahas oleh penulis telah sesuai dengan teori Islamisasi yang dipaparkan oleh al-Attas, yaitu mengenai pembebasan dari paham sekuler, materialistik, individualistik dan memasukkan elemen-elemen dan konsep kunci Islam yang relevan. Contohnya, pertama, membebaskan worldview masyarakat yang mengatakan bahwa keinginan memiliki nilai yang sama dengan kebutuhan, kemudian memasukkan konsep maslahah sebagai dasar utama dari keinginan dan kebutuhan konsumsi. Kedua, mengganti konsep utility dengan konsep maslahah. Ketiga, membatasi konsep barang dan jasa dengan istilah halalan thayyiban. Keempat, mengganti asumsi yang salah mengenai 'sumber daya alam terbatas', dengan memasukkan asumsi bahwa sumber daya alam tidak terbatas, karena Allah akan menjamin semua rezeki atau kebutuhan hidup tiap makhluk-Nya. Terakhir, pembebasan cara pandang kepuasan konsumsi dengan tidak menjadikan kepuasan sebagai prioritas utama dalam konsumsi, kemudian memasukkan unsur maslahah sebagai landasan dasar dalam konsumsi bukan kepuasan sebagaimana dalam teori konvensional.

\section{KESIMPULAN}

Terdapat dua pendekatan metodologi yang selama ini digunakan dalam membangun ilmu ekonomi Islam. Yaitu all-or-nothing aproach dan step by step aproach. ${ }^{60}$ Pendekatan pertama berpegang pada prinsip 'syariah total atau tidak sama sekali', pada pendekatan ini seluruh teori dan konsep ekonomi konvensional dinegasikan dan diruntuhkan, untuk kemudian dibangun ilmu ekonomi Islam dengan definisi dan konseptualisasinya sendiri. Adapun pendekatan kedua merupakan pendekatan gradual tahap demi tahap. Dalam pendekatan ini terjadi proses filterisasi ilmu ekonomi konvensional dengan mengeliminasi konponen-komponen yang bertantangan dengan ajaran Islam.

Islamisasi konsep keinginan dan kebutuhan dalam konvensional dengan membebaskan worldview masyarakat yang mengatakan bahwa keinginan memiliki nilai yang sama dengan kebutuhan, kemudian memasukkan konsep maslahah sebagai dasar utama dari keinginan dan kebutuhan konsumsi. Adapun Islamisasi konsep barang dan jasa dengan membatasi konsep barang dan jasa dengan istilah halalan thayyiban. Sedangkan Islamisasi konsep kepuasan dalam

60 Zubair Hassan, "Islamization of Knowledge: Issue And Agenda", dalam IIUM Journal of Economics and Management, (Vol.6, No. 2 1998), p. 32 
konvensional dengan membebaskan cara pandang masyarakat terhadap kepuasan konsumsi dengan tidak menjadikan kepuasan sebagai prioritas utama dalam konsumsi, lalu memasukkan unsur maslahah sebagai landasan utama dalam konsumsi bukan kepuasan.

\section{REFERENSI}

Al-Qur'an

Al-Attas, Naquib. 1978. Islam and Secularism. Kuala Lumpur: (ABIM); reprint, Kuala Lumpur: (ISTAC), 1978.

1995. Prolegomena. Kuala Lumpur: International Institute of Islamic Thought and Civilization (ISTAC).

Al-Faruqi, Isma'il Raji. 1982. Islamization of Knowledge: General Principles and Work Plan. Herndon, U.S.A: International Institute of Islamic Thought.

1992. Al-Tawbid: Its Implications for Thought and Life. Herndon, Virginia, U.S.A:

, International Institute of Islamic Thought.

1995. Islamisasi Pengetahuan (terj). Bandung: Pustaka.

Amalia, Euis. 2010. Sejarah Pemikiran Ekonomi Islam. Depok: Gramata Publishing.

Anto, Hendri. 2003. Pengantar Ekonomika Islami. Yogyakarta: EKONESIA.

As-Syatibi, Imam. 1997. al-Muwafaqat fi Ushul al-Syari'ah. jilid. 2. Dar Ibn Affan.

Beik, Irfan Syauqi. "Islamisasi Ilmu Ekonomi”, dalam jurnal Islamiconomic. Vol. 7, No. 2, JuliDesember 2016.

Chapra, Umer. 2002. Masa Depan Ilmu Ekonomi: Perspektif Islam, penerj. Ikhwan Abidin. Jakarta: Gema Insani Press.

Darras, Muhammad Abdullah. 1970. al-Din, Ed. 2. Kuwait: Darul-Qalam.

Daud, Wan Mohd. Nor Wan. 1991. The Beacon on the Crest of a Hill-A Brief History and Philosophy of the International Institute of Islamic Thought and Civilization (ISTAC). Kuala Lumpur: ISTAC Malaysia.

Haneef, Muhammad Aslam. 2005. A Critical Survey Of Islamization Of Knowledge. Malaysia: IIUM.

Hassan, Zubair. "Islamization of Knowledge: Issue And Agenda", dalam IIUM Journal of Economics and Management. Vol.6, No. 21998.

Hoetoro, Arief. 2007. Ekonomi Islam: Pengantar Analisis Kesejarahan dan Metodologi. Malang: BPFE. 
Kahf, Monzer. 1995. Ekonomi Islam: Telaah Analitik terhadap Fungsi Sistem Ekonomi Islam, penerj. Machnun Husein. Yogyakarta: Pustaka Pelajar.

Kayed, Rasem N. "Islamic Entrepreneurship: A Case Study of Saudi Arabia", World Scientific Jurnal of Development Entrepreneurship. Vol. 15, No. 4, 2010.

Khallaf, Abdul Wahab. Ilm Ushul Figh. Kairo: Dar al-Qolam.

Masykuroh, Ely. 2008. Pengantar Teori Ekonomi "Pendekatan Pada Teori Ekonomi ISLAM. Yogyakarta: STAIN Ponorogo Press.

Muhaimin. Konsepsi Pendidikan Islam, Sebuah Telaah Komponen Dasar Kurikulum. Solo :Ramadhani.

Muhammad. 2005. Ekonomi Mikro Dalam Perspektif Islam. Yogyakarta: BPFE.

Muslih, Kholid et. al,. 2018. Worldview Islam. Ponorogo: UNIDA Gontor Press.

Nurnasrina. "Ekonomi Islam Sarana Dalam Mewujudkan Ekonomi Masyarakat Madani”, Hukum Islam. Vol. XIII, No. 1, November 2013.

Ragab, Ibrahim A. "On The Nature and Scope of the Islamization Process: Towards Conceptual Clarification", dalam Intelectual Discourse, Internation Islamic University Malaysia. Vol. 3, No. 2, 1995.

Safi, Louay M. 1996. The Foundation of Knowledge: A comparative Study in Islamic and Western Method of Inquiry. Malaysia: IIUM Press.

Samuelson, Paul A. et. al. 2010. Economic. New York: McGraw-Hill.

Setyowati, Endang et. al. 2003. Ekonomi Mikro Pengantar. Yogyakarta: FTIE YKPN.

Sudarsih, Sri. 2007. Konsep Hedonisme Epikuros Dan Situasi Indonesia Masa Kini. Semarang: UNDIP.

Sudarsono, Heri, Konsep ekonomi Islam: suatu pengantar, (Ekonisia: Yogyakarta, 2002)

Sukirno, Sadono. 2013. Mikro Ekonomi Teori Pengantar, Ed. 3. Jakarta: PT Raja Grafindo Persada.

Weber, Max. 1958. The Protestant Ethic and the Spirit of Capitalism. New York: Charles Scribners' Sons.

Yohanes, S K. dan Peter, R P. "Segmentasi Gaya hidup pada Mahasiswa Program Studi Pemasaran Universitas Kristen Petra”, Jurnal Jurusan manajemen Pemasaran, Fakultas Ekonomi Universitas Kristen Petra, 2016.

Zarqa, Muhammad Anaz. "Islamization of Economic: The Concept and Methodology", dalam Jurnal J.KAU: Islamic Economics. Vol. 16, No. 1, 2003. 